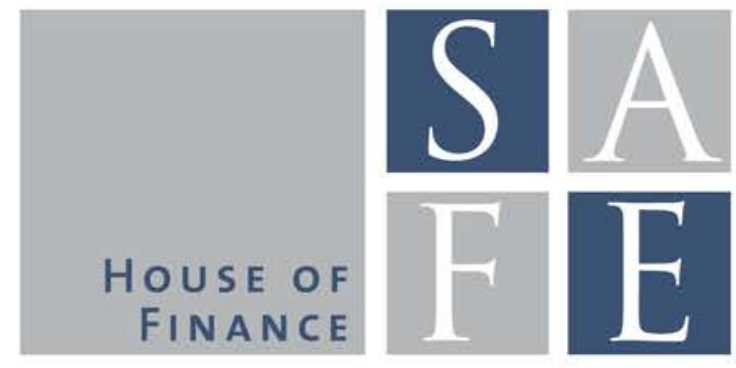

WORKING PAPER SERIES

Jens-Hinrich Binder

\title{
Resolution Planning and Structural Bank Reform within the Banking Union
}

SAFE Working Paper No. 81

SAFE I Sustainable Architecture for Finance in Europe A cooperation of the Center for Financial Studies and Goethe University Frankfurt 


\title{
Resolution Planning and Structural Bank Reform within the Banking Union
}

\author{
Jens-Hinrich Binder ${ }^{*}$
}

In the aftermath of the global financial crisis, both resolution planning, i.e. contingency planning by both regulated institutions and public authorities in order to prepare their actions in financial crisis, and concepts for structural bank reform have been identified as possible solutions to ending "Too Big To Fail” and foster market discipline among bank owners, bank managers and investors in bank debt. Both concepts thus complement the global quest for reliable procedures and tools for bank resolution that would minimise systemic implications once large and complex financial institutions have reached the stage of insolvency. Given the complex task of orchestrating swift and effective resolution actions, especially with regard to cross-border banking groups and financial conglomerates, planning ahead in good times has since been widely recognised as crucial for enhancing resolvability. At least part of the impediments to resolution will be found in organisational, financial and legal complexity that has evolved in banks and groups over time. To remove these impediments, interference with existing corporate and group structures is all but inevitable. However, in both international standard setting and at the European Union level, issues related to resolution planning (within the context of bank resolution reform) and structural banking reforms to date have been discussed rather separately. This lack of consistency is questionable, given the obvious need to reconcile both approaches in order to facilitate effective implementation and enforcement especially with regard to large, complex banking groups. Based on an analysis both of the Bank Recovery and Resolution Directive and the SRM Regulation, this paper explores how these problems could be dealt with within the context of the European Banking Union.

Keywords: Bank Resolution; Resolution Planning; Living Wills; Structural Bank Reform; Banking Union

\footnotetext{
* Professor of Law, Chair of Private Law and Commercial Law, Eberhard-Karls-Universitaet, Tuebingen, Germany; E-mail: binder@jura.uni-tuebingen.de. The present version of the paper was prepared for the conference "European Banking Union: Prospects and Challenges", on 21-22 November 2014, at the University of Buckingham. Parts of the paper build on research presented at conferences at the Universities of Munich and Bad Homburg in July and October 2014, respectively. The author would thank participants in all three events for numerous insightful comments. He gratefully acknowledges research support from the Research Center SAFE, funded by the State of Hesse initiative for research LOEWE.
} 


\section{Introduction}

Among the global regulatory responses to the global financial crisis, the development of harmonised concepts for the reorganisation and resolution for large, complex, internationally active banks and banking institutions clearly has been one of the most important aspects. Both in international fora ${ }^{1}$ and at the national levels, ${ }^{2}$ regulators, standard setters and legislators have come to agree on a set of specific resolution tools, partly innovative and partly based on precedents in national legislation prior to the crisis. ${ }^{3}$ However, notwithstanding the emergence of a specific set of instruments for crisis management by public authorities, accepted as reflecting international best practice and expected to be used in a broadly consistent way across jurisdictional borders in future bank insolvencies, the residual problems associated with the resolution of large, complex, internationally active banks and banking groups will continue to create significant impediments to the swift and effective management of individual insolvencies and the ability to contain its repercussions on the stability of national and international markets. Potential sources of such problems range from the complexity and opacity of existing legal structures of firms and groups, including the statutory and contractual frameworks for intra-group funding arrangements, to organisational issues, such as intra-group arrangements for IT support, conflicting national legal frameworks (in particular outside the EU, where the recent harmonisation of the legal framework does not apply), and conflicting national powers and interests. ${ }^{4}$

\footnotetext{
${ }^{1}$ See, in particular, Basel Committee on Banking Supervision, "Report and Recommendations of the CrossBorder Bank Resolution Group” (2010), available at www.bis.org/publ/bcbs169.pdf; Financial Stability Board, "Key Attributes of Effective Resolution Regimes for Financial Institutions" (October 2011), available at www.financialstabilityboard.org/publications/r_111104cc.pdf.

${ }^{2}$ E.g., for the United States, Dodd-Frank Wall Street Reform and Consumer Protection Act of 2010, Pub. L. No. 111-203, 124 Stat. 1376 (2010), Title II - 'Orderly Liquidation Authority’. Within the EU, a harmonised framework for the resolution of banks has been adopted with Directive 2014/59/EU of the European Parliament and of the Council of 15 May 2014 establishing a framework for the recovery and resolution of credit institutions and investment firms and amending Council Directive 82/891/EEC, and Directives 2001/24/EC, 2002/47/EC, 2004/25/EC, 2005/56/EC, 2007/36/EC, 2011/35/EU, 2012/30/EU and 2013/36/EU, and Regulations (EU) No 1093/2010 and (EU) No 648/2012, of the European Parliament and of the Council, OJ L 173 of 12 June 2014, p. 190, Title IV - 'Resolution'. For the Banking Union, broadly identical instruments have since been adopted by the provisions of Part II, Chapter 3, of Regulation (EU) No 806/2014 of the European Parliament and of the Council of 15 July 2014 establishing uniform rules and a uniform procedure for the resolution of credit institutions and certain investment firms in the framework of a Single Resolution Mechanism and a Single Resolution Fund and amending Regulation (EU) No 1093/2010, OJ L 225 of 30 July 2017, p. 1.

${ }^{3}$ For further discussion of the historical roots, focusing on the BRRD, see, e.g., Jens-Hinrich Binder, 'Resolution: Concepts, Requirements and Tools', conference paper (September 2014), available at http://ssrn.com/abstract=2499613, at pp. 13-14.

${ }^{4}$ See, for further discussion of these aspects with regard to the BRRD, Binder, supra n. 3, pp. 11-13, 29-38. And see generally John Armour, 'Making Bank Resolution Credible' (February 11, 2014), in: E. Ferran, N. Moloney and J. Payne (eds.), Oxford Handbook of Financial Regulation (Oxford: Oxford University Press 2014) (preprint available at SSRN: http://ssrn.com/abstract=2393998).
} 
In this light, both international standard setters and EU and national legislators have concluded that reactive tools for the management of financial institutions insolvency, if at all feasible, have to be complemented and preceded by preventive steps to enhance resolvability ex ante, which has to include both the identification of possible impediments to swift resolution and, where possible, the removal of such impediments in 'good times', before a crisis hits. Efforts to that end have essentially been made in two different but functionally related forms:

First, reflecting an international trend, ${ }^{5}$ the recent EU Directive establishing a framework for the recovery and resolution of credit institutions and investment firms (the 'BRRD') ${ }^{6}$ and the EU Regulations that jointly establish the Banking Union authorities (the 'SSM Regulation' and 'SRM Regulation', respectively) ${ }^{7}$ have established a broadly identical regime for preventive contingency planning by both the relevant institutions and groups ('recovery planning') ${ }^{8}$ and relevant supervisory and resolution authorities ('resolution planning') ${ }^{9}$. It is expected that both recovery plans, or "living wills", of banks and resolution plans of their counterparts at the level of resolution authorities will play an important, perhaps even crucial role: as precommitments for both institutions and authorities to specific options for resolutions, which could help to identify and indeed to mitigate impediments to swift resolution, as a means to reduce complexity in both banks and decision-making processes among authorities and as vehicles for reliable burden-sharing arrangements ex ante. ${ }^{10}$

Secondly, not just the United States ${ }^{11}$ and the United Kingdom, ${ }^{12}$ the forerunners in this regard, but also a number of jurisdictions in Continental Europe ${ }^{13}$ have adopted legislative steps

\footnotetext{
${ }^{5}$ See, in particular, Basel Committee, supra n. 1, at paras. 94-97, and FSB, supra n. 1, pp. 15-18, and see infra, II. 1. And see, for general discussion and analysis, Emilios Avgouleas, Charles Goodhart and Dirk Schoenmaker, 'Bank Resolution Plans as a catalyst for global financial reform', J. Financial Stability (2013), 210. On the international background, see also Eva Hüpkes, '”Living Wills" - An International Perspective”, in: A. Dombret and P. Kenadjian (eds.), The Bank Recovery and Resolution Directive - Europe's Solution for "Too Big To Fail" (2013), p. 71; Nizan Geslevich Packin, 'The Case Against the Dodd-Frank Act's Living Wills: Contingency Planning Following the Financial Crisis', 9 Berkeley Bus. L.J. 29, 37-38 (2012).

${ }^{6}$ Supra, n. 2.

${ }^{7}$ Council Regulation (EU) 1024/2013 of 15 October 2013 conferring specific tasks on the European Central Bank concerning policies relating to the prudential supervision of credit institution, OJ L 287 of 29 October 2013, p. 63 (hereafter: the 'SSM Regulation'). For the SRM Regulation, see supra, n. 2.

${ }^{8}$ See BRRD, articles 5-9; SSM Regulation, article 4(1)(i), and, for further discussion, infra, sections II. 2. and III.

${ }^{9}$ See BRRD, articles 10-14; SRM Regulation, articles 8 and 9, and, for further discussion, infra, sections II. 3. and III.

${ }^{10}$ See, e.g., Avgouleas et al., supra n. 5, at pp. 212-213; and see (with focus on the US approach) Adam Feibelman, 'Living Wills and Pre-commitment', 1 Am. U. Bus. L. Brief 95 (2012); Packin, 9 Berkeley Bus. L.J. 29, 37-38 (2012).

${ }^{11}$ With $\S 619$ of Dodd-Frank Wall Street Reform and Consumer Protection Act of 2010, Pub. L. No. 111-203, 124 Stat. 1376 (2010).

${ }^{12}$ With the Financial Servies (Banking Reform) Act 2013 (ch. 33).
} 
towards a comprehensive structural reform of banking, which essentially aim, in one form or the other, at the insulation of at least some traditional commercial banking activities from the risks associated with investment banking. At the EU level, negotiations are underway over a Commission proposal for a Regulation on structural bank reform, ${ }^{14}$ which takes up earlier recommendations by the High-Level Expert Group on Reforming the Structure of the EU Banking Sector, chaired by Bank of Finland Governor Erkki Liikanen, which were published in $2012 .^{15}$

Both developments are clearly related from a functional perspective. Indeed, one of the motives for structural reforms, in addition to the preservation of certain systemically relevant business functions, has been to remove impediments to effective crisis resolution. ${ }^{16}$ And, as matter of course, policy choices made in the process of resolution planning will inevitably have a bearing on the legal and organisational structure of firms and groups, as will any measure aiming at a re-design of existing business models. At least within Europe, however, neither the academic debate nor the relevant political and legislative reform projects have fully recognised the interrelation between the two aspects so far. Both at the EU and at the national levels, the legal framework for bank resolution and for resolution planning has been adopted ahead of structural reform projects, forcing the relevant authorities and the industry to draw up recovery and resolution plans that could be rendered meaningless if, and to the extent that, structural bank reforms were to enforce substantial changes to existing firm and group structures in the future. It is only very recently that initiatives have been taken to re-integrate both developments at the international standard setting level, but with little tangible results so far: In a report on "Structural Banking Reforms", addressed to the November 2014 G 20 summit, the Financial Stability Board for the first time expressly recognises the need for greater consistency in this respect and calls for future work towards this objective. ${ }^{17}$

\footnotetext{
${ }^{13}$ For Belgium, see Loi relative au statut et au contrôle des établissements de crédit, 25 April 2014, Moniteur Belge Ed. 2, 7 June 2014, p. 36794, articles 117-33. For France, see Loi no. 2013-672 du 26 juillet 2013 de séparation et de régulation des activités bancaires, Journal Officiel de la République Française no. 0173 du 27 juillet 2013, p. 12530. For Germany, see Gesetz zur Abschirmung von Risiken und zur Planung der Sanierung und Abwicklung von Kreditinstituten und Finanzgruppen, 7 August 2013, Bundesgesetzblatt Part I, p. 3090. And see, for a comparative discussion of these reforms, Jens-Hinrich Binder, 'To ring-fence or not, and how? Key questions for structural bank reform in Europe’, working paper, forthcoming on SSRN (January 2015).

${ }^{14}$ EU Commission, Proposal for a Regulation of the European Parliament and the Council on structural measures improving the resilience of EU credit institutions, COM(2014) 43 final.

${ }^{15}$ High-Level Expert Group on Reforming the Structure of the EU Banking Sector, "Final Report” (2012), available at http://ec.europa.eu/internal_market/bank/docs/high-level_expert_group/report_en.pdf ("Liikanen Report”).

${ }^{16}$ See, e.g., Liikanen et al., supra n. 15, at pp. 95-97 (stressing the need to enhance resolvability).

${ }^{17}$ Financial Stability Board, 'Structural Banking Reforms. Cross-border consistencies and global financial stability implications. Report to G20 Leaders for the November 2014 Summit', 27 October 2014, available at www.financialstabilityboard.org/publications/r_141027.pdf.
} 
Against this backdrop, the present paper seeks to present an analysis of how the existing requirements for resolution planning, on whose implementation in practice work has already begun, could possibly be reconciled with existing proposals for structural reforms of banks and banking groups within Europe in future supervisory practice. To be sure, the problems related to resolution planning go much further than that. As resolution planning is essentially about the choice between different resolution instruments ex ante, and thus the fundamental strategies to be employed with regard to both domestic and cross-border cases in the future, a significant part of the relevant policy decisions under the new resolution framework will have to be made at the planning stage rather than at the point in time where the relevant institution or group enters into resolution. Resolution plans, therefore, will have to address some highly technical fundamental questions that, even after the adoption of the BRRD, are still under consideration both at the European and the international levels, and they will do so on the basis of complex prognoses with regard to both the future financial condition of the relevant institutions or groups and future market conditions. ${ }^{18}$ Given the dynamic nature of financial markets, recovery and resolution plans are unlikely to be of any use if seen as "blueprints" for future action: The future inevitably will look different from the scenarios anticipated in the drafting process, and different conditions in real life will inevitably necessitate approaches that differ from those identified in good times. ${ }^{19}$ Nonetheless, recovery and resolution plans certainly can help both banks and their supervisors in a number of ways. First and foremost, they are likely to enhance the mutual understanding of business structures, which in turn can be useful in that it could alert both sides as to potential impediments to resolution. If, for example, the planning process reveals a group's dependence on a centralised IT infrastructure provided by a group member, resolution action with regard to other members of the group may be confronted with severe impediments if these services are not available. Such findings could then inform preparatory action by both the banks and the relevant authorities to help mitigate these problems in advance. Similarly, with regard to cross-border settings, such procedures could be used by the relevant authorities in different jurisdictions to identify potential obstacles to the future orchestration of resolution action in group settings. Thus, while neither recovery nor resolution plans are likely to provide blueprints for a specific course of action, they certainly will play an important role in future practice - a role that can, perhaps, best be characterised as a roadmap which should inform future action and identify potential problems but leave sufficient flexibility for adaptation to the individual conditions of future crisis.

\footnotetext{
${ }^{18} \mathrm{Cf}$., for a detailed discussion of the relevant aspects and problems in this respect (focusing on the legal framework under the US Dodd-Frank Act, but in principle nonetheless applicable to European institutions), Packin, 9 Berkeley Bus. L.J. 29, 39-72 (2012).

${ }^{19}$ Cf. ibid., pp. 75-77.
} 
These potential benefits of rigorous recovery and resolution planning are likely to be particularly important in the context of groups, where complex intra-group arrangements significantly enhances the logistic problems caused by any insolvency of a major financial institution. Perhaps most importantly in this regard, resolution planning will have to define whether groups will be resolved under what has become known as a "single point of entry" approach, i.e. with resolution action taken only with regard to the parent company, or under a "multiple point of entry" approach, whereby individual group companies will be subjected to resolution. ${ }^{20}$ Decisions made in this respect will, in turn, have to be reconciled with policies adopted in relation to regulatory minimum requirements for debt and capital instruments eligible for bail-in (known as "minimum requirements on capital instruments and eligible liabilities (MREL)", ${ }^{21}$ or in the international standard setting discussion, as "total loss absorbing capacity (TLAC)”, 22 agreement on which is still pending upon completion of the present paper. The focus of the present paper is related to these aspects, as existing business models, organisational and legal structures of firms and groups inevitably have to be taken into account as key determinants for the relevant policy decisions. As the relevant policy decisions are still unfolding, and as the empirical evidence on differences between different markets still appears to be extremely thin, the paper will not present any views on these aspects, however. Accepting, as a working hypothesis, that differences exist and that they could prove detrimental for the definition of consistent resolution strategies in future practice, the focus will be on how such differences could be mitigated or even removed under the powers available to the relevant authorities within Europe in general and the Banking Union in particular. In this sense, the paper is about the interplay between the relevant legal regimes, the BRRD and the SSM and the SRM Regulations, rather than on firm-specific substantive aspects of resolution planning. $^{23}$

\footnotetext{
${ }^{20}$ See, e.g., Financial Stability Board, 'Recovery and Resolution Planning for Systemically Important Financial Institutions: Guidance on Developing Effective Resolution Strategies' (16 July 1013), available at www.financialstabilityboard.org/publications/r_130716b.pdf, pp. 14-19. For a useful discussion of these approaches, see, e.g., Jeffrey N. Gordon and Wolf-Georg Ringe, 'Bank Resolution in the European Banking Union: A Transatlantic Perspective on What it Would Take', Columbia Law Review, Forthcoming, available at SSRN: http://ssrn.com/abstract=2361347.

${ }^{21}$ See BRRD, article 45 (requiring Member States to ensure minimum levels). The EBA has released draft 'Technical Standards on minimum requirements on own funds and eligible liabilities (MREL)' for consultation on 28 November 2014 (EBA/CP/2014/41, available at www.eba.europa.eu/regulation-and-policy/recovery-andresolution). Unlike the FSB's proposals for standards on total loss absorbing capacity (next footnote), this proposal does not specifically address the compatibility with SPOE and MPOE solutions, however.

${ }^{22}$ Financial Stability Board, 'Adequacy of loss-absorbing capacity of global systemically important banks in resolution. Consultative Document', 10 November 2014, available at www.financialstabilityboard.org/wpcontent/uploads/TLAC-Condoc-6-Nov-2014-FINAL.pdf; see also Financial Stability Board, supra n. 20, pp. 7-8.

${ }^{23}$ For a detailed discussion of which, see, again, Packin, 9 Berkeley Bus. L.J. 29, 39-72 (2012).
} 
Unlike the requirements for resolution planning under Title I, § 165(d) of the US Dodd Frank Act, which have already triggered a lively debate in the academic literature, ${ }^{24}$ and unlike the various structural bank reform projects, ${ }^{25}$ the harmonised regime for recovery and resolution planning within the Banking Union and the EU more generally has not attracted much attention in the academic literature yet. For this reason, the paper will start with a rather extensive analysis of the relevant parts of both the BRRD and the SSM and SRM Regulations, respectively (infra, sections $I I$ and $I I I)$. Section $I V$ will then seek to explore the potential future practice, specifically with regard to the key questions that have motivated this paper: How will the authorities use their powers to influence the choice of organisation hitherto left exclusively to the boards of banking institutions and banking groups? And, more specifically: is a consistent approach to recovery and resolution planning at all conceivable without fundamental changes to existing, highly diverse, market structures, business models and corporate structures within Europe?

From the start, three caveats are appropriate in order to further define the scope of the paper: First, it hardly makes sense to focus exclusively on resolution planning by resolution authorities and to exclude "recovery planning," or "living wills," on the part of the regulated industry. Both concepts are derived from similar considerations and, as will be discussed in further detail below, the relevant provisions of both BRRD and the SSM and SRM regulations are highly interconnected. In line with the international discussion, ${ }^{26}$ the term "resolution planning” will be used throughout in a broad, non-technical sense, i.e., not restricted to the plans to be drawn up by resolution authorities within the new EU framework. Secondly, it is, as of late 2014, far too early to predict what the future practice of authorities at both national and Union levels will look like, since some substantial questions, as mentioned above, are still under consideration, and in view of a significant amount of discretion granted to them under the relevant legal instruments. In this light, the intention is not to offer speculations as to the future policy, although suggestions will be made as to which way the authorities could, and perhaps, might, proceed on the basis of their powers under the new framework. And thirdly, it will not be possible to explore, given both the limits of this paper and the lack of reliable,

\footnotetext{
${ }^{24}$ E.g., Clay R. Costner, 'Living Wills: Can a Flexible Approach to Rulemaking Address Key Concerns Surrounding Dodd-Frank’s Resolution Plans?’, 16 N.C. Banking Inst. 134 (2012); Feibelman, supra n. 10; Joseph Karl Grant, 'Planning for the Death of a Systemically Important Financial Institution Under Title I § 165(d) of the Dodd-Frank Act: The Practical Implications of Resolution Plans or Living Wills in Planning a Bank's Funeral', 6 Va. L. \& Bus. Rev. 467 (2012); Randall D. Guynn, 'Resolution Planning in the United States', in: Dombret and Kenadjian, supra n. 5, p. 109; Packin, 9 Berkeley Bus. L.J. 29 (2012).

${ }^{25}$ For detailed discussion and review of the literature, see Binder, supra n. 13.

${ }^{26}$ See, again, Avgouleas et al., supra n. 5; Hüpkes, supra n. 5.
} 
cross-country empirical evidence in this respect, ${ }^{27}$ the full range of complicated policy issues pertaining to the potential merits and the unknowns of structural bank reform. While the importance of these aspects can hardly be overstated, and while further research in this regard is certainly critical for the evaluation and refinement of the incoming regulatory reforms, the objective of this paper is rather to identify some key questions that are likely to become relevant in the context of resolution planning before long, and thus to help prepare the ground for further debate.

\section{The legal framework for recovery and resolution planning under the BRRD}

\section{THE FRAMEWORK IN CONTEXT}

The BRRD's provisions on recovery and resolution planning, which have also been the blueprint for the corresponding regime under the SSM and SRM regulations, ${ }^{28}$ clearly reflect earlier work promulgated by the Financial Stability Board in its "Key Attribute of Effective Resolution Regimes for Financial Institutions”, which were published in October 2011 and also informed the harmonised set of resolution tools under the BRRD. ${ }^{29}$ Section 11 with Annex III of the Key Attributes set out in some detail requirements for the development and on-going reviews of recovery and resolution plans by institutions and resolution authorities, including for the cooperation of home and host country authorities. In many respects, this document can be seen as a model for the BRRD's provisions on recovery and resolution planning. Under the BRRD, the responsibilities for recovery and resolution planning under the BRRD have been arranged in a rather complex way, reflecting the FSB's Key Attributes approach to recovery and resolution planning. ${ }^{30}$ In this framework, as indicated above, supervisory and resolution authorities respectively are assigned a set of powers relating to the assessment of recovery plans (which are to be developed by the institutions) ${ }^{31}$ and the development of resolution plans and the assessment of the resolvability of institutions and groups. ${ }^{32}$ For both types of

\footnotetext{
${ }^{27}$ For a more detailed analysis of the available evidence and of the need for further research, see Binder, supra n. 13.

${ }^{28}$ See infra, III.

${ }^{29}$ Supra n. 1.

${ }^{30}$ See FSB, supra n. 1, pp. 15-18.

${ }^{31}$ BRRD, articles 6 and 8.

${ }^{32}$ BRRD, articles 10, 12 and 13 (development of resolution plans) and 15-18 (assessment of resolvability).
} 
plans, simplified obligations apply to less complex and interconnected institutions with a low risk profile, which will not be discussed any further in this paper. ${ }^{33}$

Fully in line with the international standards and a growing convergence of international best practice, ${ }^{34}$ the concept underlying the relevant BRRD provisions in this respect is rather simple: to prepare for more effective recovery efforts by the banks themselves and for more effective administrative resolution action by identifying, and addressing, risks in advance. By requiring both banks and relevant authorities to pre-commit to a range of specific options, the concept thus serves to reinforce the notion that, following the global crisis, all financial institutions, regardless of size, complexity and interconnectedness, should be resolvable. ${ }^{35}$ In this regard, resolution planning is an essential part of a market-oriented incentive structure that is hoped to substitute taxpayer funded bail outs of institutions deemed too big to fail, too complex to fail and/or too interconnected to fail in the future. However, while simple in theory, the concept has become quite complex in the form it was adopted by the BRRD and the SSM and SRM regulations. In this regard, as will be explored in more detail below, the relevant provisions of these three legal instruments are just another example of the problems characteristic of the interplay between the substantive and procedural regulations applicable throughout the EU on the one hand, and the legal and institutional framework for the Banking Union on the other generally.

\section{RECOVERY PLANS}

Under the BRRD, individual recovery plans are to be developed by those regulated institutions that are not part of a group subject to consolidated supervision ${ }^{36}$ (for which group resolution plans have to be developed ${ }^{37}$ ). With both individual and group recovery plans, the purpose is to identify possible "measures to be taken by those institutions for the restoration of their financial position following a significant deterioration", including "possible measures which could be taken by the management of the institution where the conditions for early intervention are met". ${ }^{38}$ These plans have to be updated at least annually, or after a change to the legal or organisational structure of the institution. ${ }^{39}$ As part of the overall objective to pro-

\footnotetext{
${ }^{33}$ BRRD, article 4; SRM Regulation, article 11.

${ }^{34}$ See, again, Avgouleas et al., supra 5; Hüpkes, supra n. 5.

${ }^{35}$ See also BRRD, preamble, recitals 1, 5, 25.

${ }^{36}$ BRRD, article 5.

${ }^{37}$ BRRD, article 7.

${ }^{38}$ BRRD, preamble, recitals 21 and 22, respectively, and article 5(6).

${ }^{39}$ BRRD, article 5(2).
} 
tect fiscal interests in bank resolution, ${ }^{40}$ recovery plans shall not "assume any access to or receipt of extraordinary public financial support", ${ }^{41}$ but may provide for the use of "central bank facilities”, that is, central bank loans against collateral. ${ }^{42}$

Recovery plans are to be based on an in-depth analysis of each institution's, or group's, financial and organisational position. This is specified in further detail by Section A of the Annex to the Directive, which lists the range of information to be included in recovery plans. These provisions have since been complemented by EBA draft technical standards on the contents of recovery plans ${ }^{43}$ and EBA guidelines on scenarios to be used in recovery plans. ${ }^{44}$ In particular, the plan will have to identify possible impediments to the execution of the plan, ${ }^{45}$ critical functions that will have to be preserved in the interest of financial stability, ${ }^{46}$ as well as adequate contingency funding sources, ${ }^{47}$ and it will have to set out how the institution seeks to restore its capital base, reduce risk and leverage, restructure liabilities and business lines, ensure the continuity of essential operational systems, and facilitate the sale of assets or business lines. ${ }^{48}$ For groups, recovery plans have to be drawn up by Union parent undertakings and provide the relevant information with regard to both the parent undertaking and each individual subsidiary. ${ }^{49}$ In both cases, individual institutions and groups, the plans shall include a framework of indicators "which identifies the points at which appropriate actions referred to in the plan may be taken". 50

Importantly, recovery plans under the BRRD - and, in fact, globally ${ }^{51}$ - will not remain in the sphere of the institution or group, but will be subjected to scrutiny by the relevant supervisory authority, or "competent authority”, in the terminology of the Directive. For individual institu-

\footnotetext{
${ }^{40}$ See also BRRD, preamble, recitals 5 and 31.

${ }^{41}$ BRRD, article 5(3).

${ }^{42}$ BRRD, article 5(4).

${ }^{43}$ EBA, Final Draft Regulatory Technical Standards on on the content of recovery plans under Article 5(10) of Directive 2014/59/EU establishing a framework for the recovery and resolution of credit institutions and investment firms, EBA/RTS/2014/11 (18 July 2014), available at www.eba.europa.eu/regulation-and-policy.

${ }^{44}$ EBA, Guidelines on the range of scenarios to be used in recovery plans, EBA/GL/2014/06 (18 July 2014), available at www.eba.europa.eu/regulation-and-policy.

${ }^{45}$ BRRD, Annex, Section A, point 6; see also Draft Regulatory Standards, supra n. 43, article 6(5)(d) ('feasibility assessment').

${ }^{46}$ BRRD, Annex, Section A, point 7; see also Draft Regulatory Standards, supra n. 43, article 6(3)(b).

${ }^{47}$ BRRD, Annex, Section A, point 11; see also Draft Regulatory Standards, supra n. 43, article 6(3)(c), 5(b).

${ }^{48}$ BRRD, Annex, Section A, points 10, 12-14, 16 and 17, respectively; see also Draft Regulatory Standards, supra n. 43, article 6(4).

${ }^{49}$ BRRD, article 7(1).

${ }^{50}$ BRRD, article 9.

${ }^{51}$ On the role of relevant resolution authorities generally, see Hüpkes, supra n. 5, at p. 81.
} 
tions, this will be the home supervisor as defined by article 2(21) of the BRRD and article $4(1)(40)$ of the $\mathrm{CRR}^{52}$ in cooperation with the competent authorities of Member States where significant branches are located. ${ }^{53}$ Specifically, the authority, under article 6(2) of the Directive, will be required to assess the plan's compliance with the requirements set out in article 5 (just discussed) and the following criteria:

“(a) the implementation of the arrangements proposed in the plan is reasonably likely to maintain or restore the viability and financial position of the institution or of the group, taking into account the preparatory measures that the institution has taken or has planned to take;

(b) the plan and specific options within the plan are reasonably likely to be implemented quickly and effectively in situations of financial stress and avoiding to the maximum extent possible any significant adverse effect on the financial system, including in scenarios which would lead other institutions to implement recovery plans within the same period.”

In addition, article 2(3) of the BRRD requires that the competent authority "shall take into consideration the appropriateness of the institution's capital and funding structure to the level of complexity of the organisational structure and the risk profile of the institution”. These criteria will be complemented by regulatory technical standards, a draft of which has been released by EBA in July 2014. ${ }^{54}$

The plan shall also be communicated to the relevant resolution authority, which may conduct a further assessment "with a view to identifying any actions in the recovery plan which may adversely impact the resolvability of the institution, and make recommendations to the competent authority with regard to those matters." ${ }^{55}$ On this basis, the competent authority is empowered, in a gradual approach, to (a) notify the institution of "material deficiencies" or "material impediments" to the implementation of the plan and require the institution to submit a revised plan, and, possibly, (b) to direct the institution to make specific changes to the plan. ${ }^{56}$

\footnotetext{
${ }^{52}$ Regulation (EU) No 575/2013 of the European Parliament and of the Council of 26 June 2013 on prudential requirements for credit institutions and investment firms and amending Regulation (EU) No 648/2012, OJ L 176 of 27 June 2013, p. 1.

${ }^{53}$ BRRD, article 6(2).

${ }^{54}$ EBA, Final Draft Regulatory Technical Standards on the assessment of recovery plans under Article 6(8) of Directive 2014/59/EU (Bank Recovery and Resolution Directive - BRRD), EBA EBA/RTS/2014/12 (18 July 2014), available at www.eba.europa.eu/regulation-and-policy.

${ }^{55}$ BRRD, article 6(4).

${ }^{56}$ BRRD, article 6(5).
} 
If the institution fails to comply with such directions, even more intrusive measures may be imposed. Pursuant to article 6(6) of the Directive,

"If the institution fails to submit a revised recovery plan, or if the competent authority determines that the revised recovery plan does not adequately remedy the deficiencies or potential impediments identified in its original assessment, and it is not possible to adequately remedy the deficiencies or impediments through a direction to make specific changes to the plan, the competent authority shall require the institution to identify within a reasonable timeframe changes it can make to its business in order to address the deficiencies in or impediments to the implementation of the recovery plan.

If the institution fails to identify such changes within the timeframe set by the competent authority, or if the competent authority assesses that the actions proposed by the institution would not adequately address the deficiencies or impediments, the competent authority may direct the institution to take any measures it considers to be necessary and proportionate, taking into account the seriousness of the deficiencies and impediments and the effect of the measures on the institution's business.”

Possible changes are defined to include, inter alia, recapitalisation measures, reviews of the institution's strategy and structure, changes to the funding strategy and changes to the governance structure of the institution. ${ }^{57}$

As for group resolution plans, the requirements are broadly similar, but the framework is more complex, of course. The plans shall

"aim to achieve the stabilisation of the group as a whole, or any institution of the group, when it is in a situation of stress so as to address or remove the causes of the distress and restore the financial position of the group or the institution in question, at the same time taking into account the financial position of other group entities." 58

This will include both measures at the group level and measures at the level of the individual entities, including significant branches. ${ }^{59}$ The group recovery plan will have to be submitted to the relevant consolidating supervisor and the college of supervisors established under arti-

\footnotetext{
${ }^{57}$ BRRD, article 6(6)(3).

${ }^{58}$ BRRD, article 7(4).

${ }^{59}$ BRRD, article 7(1).
} 
cle 116 of the CRD IV ${ }^{60}$, the competent authorities of Member States where significant branches are located, the group-level resolution authority and the resolution authority of subsidiaries. ${ }^{61}$ They shall then assess the plan and endeavour to reach a joint decision. If this fails, it will be for the consolidating supervisor and for the competent authorities of subsidiaries to decide on the appropriate course of action in their turf, ${ }^{62}$ with EBA to act as arbiter between conflicting views among the relevant competent authorities. ${ }^{63}$

\section{RESOLUTION Plans}

Resolution Plans, under the BRRD, are devised as an "inhouse” exercise to be conducted by resolution authorities in consultation with the competent authorities and the resolution authorities of Member States where significant branches are located. ${ }^{64}$ The relevant institutions themselves have to play a role in their development only if, and to the extent that, the resolution authority decides to get them involved, ${ }^{65}$ and can be subjected to extensive requests for information by resolution authorities. ${ }^{66}$ Resolution plans shall explore possible responses, in the terminology of the Directive: “options for applying the resolution tools and resolution powers" defined in Title IV of BRRD, for cases of idiosyncratic failure and of failure within "broader financial instability or system wide events”. ${ }^{67}$ Again, extraordinary financial support, defined rather broadly, is ruled out as an option in this context. ${ }^{68}$ Specifically, the plan has to address, among other things, the following aspects: (1) solutions for the legal and economic separation of critical functions and business functions from other functions to ensure the continuity of such functions in insolvency, ${ }^{69}$ (2) approaches to determining the value and

\footnotetext{
${ }^{60}$ Directive 2013/36/EU of the European Parliament and of the Council of 26 June 2013 on access to the activity of credit institutions and the prudential supervision of credit institutions and investment firms, amending Directive 2002/87/EC and repealing Directives 2006/48/EC and 2006/49/EC, OJ L 176 of 27 June 2013, p. 338.

${ }^{61}$ BRRD, article 7(3).

${ }^{62}$ BRRD, article $8(3)$.

${ }^{63}$ BRRD, article 8(4)).

${ }^{64}$ BRRD, article 10(1).

${ }^{65}$ BRRD, article 10(5).

${ }^{66}$ BRRD, article 11.

${ }^{67}$ BRRD, articles 10(3) and (7).

${ }^{68}$ BRRD, article 10(4).

${ }^{69}$ BRRD, article 10(7)(c).
} 
marketing of these functions and business lines, ${ }^{70}$ (3) the funding of resolution action, ${ }^{71}$ and (4) the preservation of access to market infrastructure, e.g., payments and clearing systems. ${ }^{72}$

Broadly similar to the dual system characteristic of individual and group recovery plans, group resolution plans will have to be developed by group-level resolution authorities in cooperation with the resolution authorities of subsidiaries and in consultation with resolution authorities in Member States with significant branches. ${ }^{73}$ These plans shall identify resolution options with regard to Union parent undertakings, subsidiaries that are located within the Union, financial holding companies and parent financial holding companies located within the Union, and - subject to Title VI of the Directive - subsidiaries located in Third Countries (i.e., outside the EU). Detailed requirements apply with regard to the coordination of plans with EBA and all relevant resolution authorities, with a framework for conflict resolution similar to the one for recovery plans. ${ }^{74}$

Both individual and group resolutions will have to be developed on the basis of a so-called "assessment of resolvability", which is to be carried out by resolution authorities under articles 15 (for individual institutions) and 16 (for groups) of the Directive, respectively. The standard for this has been defined as whether or not

"it is feasible and credible for the resolution authority to either liquidate it under normal insolvency proceedings or to resolve it by applying the different resolution tools and powers to the institution while avoiding to the maximum extent possible any significant adverse effect on the financial system, including in circumstances of broader financial instability or system-wide events, of the Member State in which the institution is established, or other Member States or the Union and with a view to ensuring the continuity of critical functions carried out by the institution."75

While authorities are thus required to take into account possible repercussions of their policy decisions for markets in other Member States, whether or not this will work out as intended remains to be seen, of course, and perhaps a natural bias towards protecting own markets, market players and depositors could prove persistent in practice.

\footnotetext{
${ }^{70}$ BRRD, article $10(7)$ (g).

${ }^{71}$ BRRD, article 10(7)(i).

${ }^{72}$ BRRD, article 10(7)(l).

${ }^{73}$ BRRD, article 12(1).

${ }^{74}$ BRRD, article 13.

${ }^{75}$ BRRD, article 15(1)(2).
} 
The relevant criteria are then specified in Section C of the Annex to the Directive and include both organisational and financial aspects of resolution, as well as requirements with regard to the interconnectedness between the individual institution (or group) and counterparties and market infrastructure both within and outside the EU. If the resolution authority, in consultation with the competent authority, determines that there are "substantive impediments to the resolvability" of an institution, the authority may notify the institution accordingly, which then has to propose measures to resolve these impediments. ${ }^{76}$ If these proposals are found to be deficient, the authority may require the institution to take a broad range of alternative measures proposed by the authority, ${ }^{77}$ including the reorganising of financing arrangements, changes to the business or organisational structure and changes of the group structure. ${ }^{78}$ In the context of group resolution planning, the Directive prescribes a regime of cooperation similar to the one just described with regard to group recovery plans. ${ }^{79}$ In both cases, all measures are subject to a proportionality test. ${ }^{80}$

\section{RECOVERY AND RESOLUTION PLANS UNDER BRRD: SOME KEY FINDINGS}

Looking back to the rather complex structure just described, it is, as mentioned before, first important to note that the BRRD clearly envisages recovery and resolution planning as a twostep procedure, which is to be carried out under the auspices of the competent supervisory authority in the first step and of the resolution authority in the second. As a result, as mentioned before, resolution planning - in the technical, narrow sense - depends on the outcome of the interaction of institutions (or groups) and competent authorities with regard to recovery planning: Policy choices made with regard to recovery planning, as the first step of interference with individual firms' and groups' existing organisation and legal structure, will inevitably come with implications for resolution planning, in particular in cases where the competent authority uses its powers to impose and enforce substantial changes to business models, funding arrangements, organisational or indeed legal structures. In this sense, the Directive's requirements for the close cooperation between competent and resolution authorities are clearly necessary. Whether they are sufficient to remove practical problems is quite another story, however, and there are reasons for substantial doubts in this regard given the residual poten-

\footnotetext{
${ }^{76}$ BRRD, article 17(3).

${ }^{77}$ BRRD, article 17(4).

${ }^{78}$ BRRD, article 17(5).

${ }^{79}$ BRRD, article 18.

${ }^{80}$ BRRD, article 17(4).
} 
tial for disagreement among home and host authorities and its repercussions on the available resolution strategies. ${ }^{81}$

At any rate, the concept of recovery and resolution planning as developed under the BRRD clearly goes far beyond mere contingency planning. In fact, both the competent authorities' powers to require changes to the recovery plan and the resolution authorities' powers to enhance resolvability could be used in a way that drastically interferes with the institution's business portfolio, financial and organisational structure, including group structures. In terms of the powers available under BRRD, both competent and resolution authorities have indeed been provided with tools to accomplish no less than full-fledged market reorganization, in the sense of substantial changes in the way the industry has organised itself. Used wisely, this could indeed remove at least some of the problems preventing effective crisis resolution today, especially problems attributable to the complexity and opacity of business models and organisations. In other words: On the basis of their powers given under this part of the Directive, authorities could go a long way towards implementing fully-fledged structural reforms of banking in the relevant jurisdictions, even without a more specific formal mandate to do so.

Against this backdrop, however, the delineation of powers between supervisory and resolution authorities defined under BRRD, despite all rhetoric on coordination, consultation and cooperation, may well turn out to be a second best solution. From a functional perspective, it is probably fair to say that the framework essentially splits up what ideally should be inseparable: Although from different perspectives, both recovery and resolution planning deal with options that could be used in the event of a failure, and both regimes, for the sake of effectiveness, should be as consistent as possible. Having (at least) two authorities in charge, consistency could fall victim to conflicting views among the authorities, which in turn may adversely affect the capacity of the regime to work effectively in the interest of enhanced resolvability. There may be reasons to separate resolution powers from supervisory functions, but separating recovery from resolution planning is a different story. This problem is even more acute in the case of recovery and resolution plans for groups, where the framework for coordination between a multitude of different authorities at the national and EU levels is even more complicated. All this may result in, at best, duplicative or indeed even contradictory requirements imposed on individual institutions and groups.

\footnotetext{
${ }^{81}$ Cf., e.g., Valia S.G. Babis, 'European Bank Recovery and Resolution Directive: Recovery Proceedings for Cross-Border Banking Groups’, [2014] EBLR 459, 462 and 473-477.
} 


\section{The situation within the Banking Union: recovery and resolution planning under the SSM and SRM regulations}

If the situation under BRRD is perhaps too complicated to be fully convincing - how then does all this translate into the institutional framework for the Banking Union? In principle, the answer appears to be rather straightforward: As the ECB, in its capacity as sole supervisor, will assume the role of national competent authorities within the legal framework for recovery planning under the BRRD, it is hardly surprising that it will also assume the "supervisory tasks in relation to recovery plans", including the power to impose "structural changes", for credit institutions or groups in relation to which the ECB is the consolidating supervisor. ${ }^{82} \mathrm{In}$ addition, the ECB will replace national competent authorities for branches of credit institutions established in third countries. ${ }^{83}$ The Single Resolution Board, by contrast, will be in charge of drafting resolution plans for (1) credit institutions established in a participating Member State, (2) parent undertakings established in a participating Member State, if subject to consolidated supervision by the ECB, (3) investment firms and financial institutions established in a participating Member State, if subject to consolidated supervision by the ECB, and (4) groups, if they are considered to be significant in accordance with article 6(4) of the SSM Regulation, or if the ECB has decided to exercise directly the supervisory powers in accordance with article 6(6)(b) of the SSM Regulation. ${ }^{84}$ National resolution authorities in participating Member States will continue to be responsible for all other institutions or groups under the national laws transposing the BRRD. ${ }^{85}$ The Single Resolution Board retains some oversight powers, however, and may exercise the relevant powers directly, in particular where the national resolution authorities fail to comply with its warnings. ${ }^{86}$ Participating Member States have the right to transfer the relevant powers to the Board pursuant to article 7(5) of the SRM Regulation.

Where the Board is directly responsible, the relevant provisions are to be found in the SRM Regulation, not the national laws transposing the BRRD: Article 8 of the Regulation first sets out the procedure for the development of resolution plans for those individual entities and groups for which the Board is responsible. Within this framework, the Board shall draw up the plans after consulting the ECB or relevant national competent authorities, as well as the resolution authorities in participating Member States where the relevant entities are estab-

\footnotetext{
${ }^{82}$ SSM Regulation, article 4(1)(i).

${ }^{83}$ SSM Regulation, article 4(2).

${ }^{84}$ SRM Regulation, article 7(2).

${ }^{85}$ SRM Regulation, article 7(3).

${ }^{86}$ SRM Regulation, article 7(4).
} 
lished, and resolution authorities in non-participating Member States with significant branches. The Board may require national resolution authorities to prepare drafts for individual and group resolution plans. ${ }^{87}$ The Board shall issue guidelines and address instructions to national resolution authorities for such drafts. ${ }^{88}$ As for substantive requirements, the Regulation then basically replicates the requirements set out for individual and group resolution plans in the BRRD. ${ }^{89}$ Just as under the BRRD, the resolution plans developed by the Board shall be based on an assessment of resolvability of the individual entities and groups. In this respect, article 10 of the SRM Regulation essentially prescribes broadly the same procedure and substantive criteria as articles 15-18 of the BRRD for individual entities and groups, respectively.

\section{Possible policy options - an assessment}

\section{Authorities’ InCEntives to Change the Status Quo}

The centralisation of supervisory and resolution powers within the Banking Union is, of course, not an end in itself. It serves the fundamental objective to help remove the participating Member State's abuse of their control over domestic banking systems and, in a much quoted formulation, to 'break the link between sovereign debt and bank debt and the vicious circle which has led to over $€ 4,5$ trillion of taxpayers money being used to rescue banks in the EU. ${ }^{90}$ Within the context of the present paper, this translates into a rather simple question: Is the new regime on recovery and resolution planning likely to work more effectively within the Banking Union framework than under national legislation transposing the BRRD in nonparticipating EU Member States? In other words: The Banking Union has brought about the centralisation of powers for the scrutiny of recovery plans on the one hand and for resolution plans and the assessment of the "resolvability" of institutions and groups on the other hand, but not more than that so far - is this centralisation, as such, likely to mitigate the deficiencies

\footnotetext{
${ }^{87}$ SRM Regulation, article 8(1).

${ }^{88}$ SRM Regulation, article 8(3).

${ }^{89}$ Contrast SRM Regulation, article 8(6)-(12) with BRRD, article 10(3)-(4) and (7) and article 12(1)-(5).

${ }^{90}$ EU Commission, Communication from the Commission to the European Parliament and the Council, 'A Roadmap towards a Banking Union', 12 September 2012, COM(2012) 510 final, p. 3. See generally, Eilis Ferran and Valia S.G. Babis, 'The European Single Supervisory Mechanism', (2013) 13 Journal of Corporate Law Studies 255; Tobias H. Tröger, 'The Single Supervisory Mechanism - Panacea or Quack Banking Regulation?' European Business Organization Law Review, Forthcoming; SAFE Working Paper No. 27 (August 16, 2013), available at SSRN: http://ssrn.com/abstract=2311353; Guido Ferrarini and Luigi Chiarella, 'Common Banking Supervision in the Eurozone: Strengths and Weaknesses’, ECGI - Law Working Paper No. 223/2013 (1 August 2013), available at SSRN: http://ssrn.com/abstract=2309897; Eddy Wymeersch, 'The European Banking Union, a First Analysis', Financial Law Institute Working Paper Series WP 2012-07 (October 23, 2012), available at SSRN: http://ssrn.com/abstract=2171785; for a detailed review of the economic rationale and legal and institutional implications (in German), see also Jens-Hinrich Binder, 'Auf dem Weg zu einer europäischen Bankenunion? Erreichtes, Unerreichtes, offene Fragen’, in: Zeitschrift für Bankrecht und Bankwirtschaft (2013), 297.
} 
of the BRRD in terms of overly complicated decision making processes and the potential for contradictory decisions by supervisory and resolution authorities?

At first sight, the answer seems to be in the negative, since the need to reconcile a multitude of different views from actors at both the EU and national levels has not been removed. With the Banking Union created with a view to removing impediments to effective regulation that arise out of conflicting national turfs and interests, this would be disappointing. All in all, the framework for recovery and resolution planning under the SSM and SRM Regulations does not deviate substantially from the relevant procedures and substantive requirements under the BRRD. With the ECB and the Single Resolution Board, the Banking Union's institutions merely assume the functions otherwise allocated to national authorities under the BRRD. Just as the coordination between national competent authorities and national resolution authorities is not problem-free under the BRRD framework, so will be the coordination between the ECB in its capacity as supervisory authority and the Single Resolution Board. These problems are likely to be complicated further by the need to consult with national authorities. Against this background, the advantages of having a single authority in place for groups and institutions established within the Banking Union have been watered down considerably. Finally, with regard to Third Country relations outside the EU, it may be advantageous to have the Single Resolution Board as a “one stop” counterpart for foreign authorities. But whether this really can improve the effectiveness of cross-border resolution will also depend on whether or not the Board will be able to credibly establish consistent, harmonised strategies across the Banking Union - which is likely to be difficult in view of the residual differences between the national markets and banking systems.

On closer inspection, however, this assessment could well prove too simplistic. As mentioned before, the dimension of the powers granted under BRRD to design and enforce drastic changes to existing business models, funding arrangements and indeed corporate and group structures should not be underestimated. To be sure, the relevant regulatory policies will have to be developed on the basis of existing market structures, and will have to respect that different markets have evolved differently over time. ${ }^{91}$ This will, for the time being, preclude a "one size fits all” approach. For example, within the German banking system, different resolution strategies will have to be developed for the three major subsectors, reflecting the differences in the legal structures of commercial banks in the form of partnerships or companies, cooperative banks and banks incorporated as public law bodies under public ownership. Nonetheless, clearly not all residual differences that have developed over time invariably are

\footnotetext{
${ }^{91}$ See also BRRD, Preamble, recitals 14, 21; SRM-Regulation, Preamble, recital 44 (all requiring that the structure of the institutions and firms be duly taken into account).
} 
worth preserving, or simply have to be accepted as a fact of life. Given the obvious need to apply the new regime in a non-discriminatory way to all firms located in the EU, ${ }^{92}$ it is not unlikely that both the ECB and SRB could eventually decide to enforce greater consistency of business models, funding arrangements and the legal structures of individual firms and groups, to the extent that residual differences in this respect stand in the way of a consistent application of the resolution tools across the Banking Union (as they certainly have to date). In other words: Although subject to proportionality tests that may be relied upon by banks in defending the existing arrangements, both the ECB and - in particular - the Single Resolution Board have incentives to use their powers analysed above to accomplish substantial changes to the different markets under their control. And they are, perhaps, better placed than national authorities to use their powers free from national biases. In effect, a certain streamlining of business models and group structures could indeed be the consequence. ${ }^{93}$ Even though resolution should always be planned with a view to accommodating existing structures, effective responses to future crises - both individual and systemic - may, in the long run, be possible only with greater convergence in terms of funding models and group structures. In this sense, the problems highlighted above with regard to the effective implementation of recovery and resolution planning within the EU could well turn out to be resolvable only if the authorities used their powers with a view to forcing changes to existing market structures.

There are, in fact, signs that future regulatory policies could well be inspired by this sort of reasoning. In its recent report to the G 20 summit in November 2014, the Financial Stability Board emphasises the need for cross-border consistency in structural bank reforms, and discusses possible effects and impediments to the 'supervisability' and 'resolvability' that could be triggered by differing reforms. ${ }^{94}$ Specifically, the report argues that participating authorities

"anticipate that structural reforms promote greater alignment of business lines with legal structures within a group, both by requiring capital and liquidity to be held where the risks are located in the banking group, and by simplifying internal management and supervision. “95

As mentioned before, this is a clear signal that the interplay between the legal and organisational structure of institutions and groups on the one hand and the 'resolvability' of institu-

\footnotetext{
${ }^{92}$ This is expressly recognised both by the BRRD and the SRM Regulation, see BRRD, Preamble, recital 29; SRM Regulation, Preamble, recitals 12 and 29.

${ }^{93}$ For a similar conclusion, see Babis, [2014] EBLR, 459, 470-477.

${ }^{94}$ FSB, supra n. 17, pp. 12-17.

${ }^{95}$ FSB, supra n. 17, pp. 13-14.
} 
tions on the other hand are attracting increasing attention among regulators world-wide, and that this could lead to enhanced integration of issues pertaining to both structural bank reform and recovery and resolution planning within the more general campaign against opacity and complexity in the way banks and financial groups have come to be organised: Thus, there seems to be a growing awareness of possible impediments to resolvability originating from organisational diversity of banks, which might in turn provide incentives for regulators and supervisors to counter these effects by nudging, or forcing, the institutions and firms into substantial changes in this respect. If this assessment is correct, the responsible authorities may be expected to make wide use of their powers in order to address such impediments by 'optimising' business models and funding, organisational and legal structures of banks, and thus to enhance both the resolvability and the supervisability of the relevant entities and groups.

\section{INSTRUMENTS AND STRATEGIES}

The legal powers for accomplishing substantial changes to existing business models, funding arrangements, organisational and legal structures ex ante, that is, before the state of insolvency has been reached, have been identified above: They are to be found in the competent and resolution authorities' powers to evaluate recovery plans and assess the resolvability of institutions and firms, and the corresponding powers to impose changes to existing structures and arrangements. ${ }^{96}$ As mentioned before, these powers, while subject to a vaguely defined proportionality test, can be used in a vast range of different ways. In order to analyse precisely what this could mean for the relevant markets and market participants, it is important to note that the definition of potential strategies in this respect would not have to start from zero. Indeed, to a larger extent than with regard to the resolution tools, authorities could rely on past experience, and make use of existing approaches to preventive structural measures that have been adopted in a number of jurisdictions with a view to containing the impact of bank failure.

In this respect, structural bank reforms in the form adopted by the United States and the United Kingdom outside the Banking Union, and by Belgium, France and Germany within, ${ }^{97}$ are only one, albeit rather bold, example among others of a top-down re-engineering of existing organisational, financial and legal arrangements in cross-border banks and groups. Leaving all conceptual differences aside, all those recent examples of structural bank reforms clearly are what could be described as 'activities oriented', in the sense that they are designed to separate

\footnotetext{
${ }^{96}$ See, again, BRRD, articles 6 and 8 (assessment of recovery plans) and articles 15-18 (assessment of resolvability and corresponding powers), and see supra, II. 2. and II. 3.

${ }^{97}$ See, again, supra, nn. 11-13 and accompanying text.
} 
certain business functions of banks and protect, in one way or the other, those functions that are deemed particularly relevant in macroeconomic terms. ${ }^{98}$ While the focus is on the prevention of contagious effects in crisis by separating those functions ex ante, the expectation is that it will also be easier to formally resolve the reformed business once it has reached the proximity of insolvency once the structural reforms have drawn a clearer line between systemically important and less important functions before a crisis hits. ${ }^{99}$

In this regard, the separation of existing business functions can be classified as a functional alternative to strategies that have been employed for a long time by regulatory authorities in many jurisdictions specifically in relation to cross-border banks and banking groups, with a view to "regionalising" the fallout of individual failures on domestic markets by splitting up the firm's or group's assets and liabilities along jurisdictional borders. Such strategies are commonly referred to as the 'ring fencing' of assets and liabilities. Applied by host authorities to domestic branches of foreign-registered banks, they can take two forms: In what is known as 'ex ante ring fencing', host authorities will require that domestic branches of foreign banks, at any given point in team, maintain sufficient domestic assets to be available to domestic creditors if the foreign bank were to enter insolvency. By contrast, 'ex post ring fencing' occurs once a foreign bank has entered into insolvency liquidation or resolution. In this case, similar to secondary insolvency proceedings under general international insolvency law, host authorities responsible for supervising branches will subject the branch to a liquidation procedure that is separate from the liquidation or resolution procedure initiated and administered by home country courts or authorities. ${ }^{100}$ Where coordinated and enforced ex ante, both forms of ring-fencing, to some extent, serve similar objectives as activities-oriented structural reforms: ${ }^{101}$ From a functional perspective, the jurisdictional separation of business activities also aims at reducing complexity in the interest of enhanced resolvability, inasmuch as it reallocates the relevant bank's resources in a way that facilitates domestic crisis management without the need to rely on the home country authorities' willingness to cooperate and appropriately protect stakeholders in other jurisdictions. ${ }^{102}$ As an even more aggressive strategy, host jurisdictions could force foreign banks active within their territory to reorganise their business by way of legal separation from the foreign bank, and to conduct domestic business

\footnotetext{
${ }^{98}$ For further discussion, see Binder, supra n. 13.

${ }^{99}$ See also supra, text accompanying n. 16. This is now expressly recognised in FSB, supra n. 17, pp. 12-17.

${ }^{100}$ See, for a seminal discussion of ring-fencing in this sense, Steven L. Schwarcz, "Ring-Fencing", 87 S. Cal. L. Rev. 69 (2013) pp. 74-81; and see Binder, supra n. 13, for a detailed discussion of the merits and shortcomings in the present context. See also FSB, supra n. 17, p. 13.

${ }^{101}$ See also, noting the similarities between structural reforms and the 'subsidiarisation' of cross-border banking activities (discussed below), FSB, supra n. 17, p. 14.

${ }^{102}$ Binder, supra n. 13.
} 
exclusively through subsidiaries - or through an intermediate holding subject to supervision by host authorities - rather than through branches that would be supervised by the home authorities. ${ }^{103}$ As a result, it would be even easier for host authorities to cut out the domestic part of a group in the event of insolvency, to determine exclusively the level of capital required for this business, and to ensure that domestic assets will be available to local creditors. In this light, what has become known as the 'subsidiarisation' of foreign-owned banking business is very similar to the ring-fencing of foreign-owned branches described above, but goes even further in terms of the legal and functional separation of home and host country activities. ${ }^{104}$

As mentioned before, it is impossible within the restrictions of the present paper to present a comprehensive assessment of the merits and shortcomings of these different concepts. ${ }^{105}$ For present purposes, it is sufficient to note that all forms of forced changes to existing organisational, funding and legal structures will inevitably come with - possibly substantial - implications for the firm's or group's profitability, in terms of both short term (adjusting) and long term costs, e.g. because of a reduced efficiency. ${ }^{106}$ Moreover, the regionalisation of banking activities, which could follow from a forced separation of existing groups along jurisdictional borders, could eventually reduce market liquidity, which may be detrimental especially in distressed markets. ${ }^{107}$ There clearly are trade-offs between the resilience of the relevant financial systems, which may be furthered by such reforms, and the profitability of firms and groups, as well as the macro-economic benefits of integrated, deep markets, which may be compromised. This is not to suggest that the existence of such costs should preclude, or just deter, attempts to redesign existing business models, financial, organisational and legal structures a limine. In fact, similar trade-offs exist with regard to all aspects of the re-regulation of financial systems after the crisis, and may have to be accepted as a price to be paid for avoiding future taxpayer exposure to “Too Big To Fail” bailouts. As has been noted with regard to increases in bank capital requirements, the assessment of the merits should be done on a 'netsocial-welfare' basis, taking into account not just the costs to banks, but also the possible gains resulting from greater financial stability to the taxpayer. ${ }^{108}$ To be sure, this is a rather

\footnotetext{
${ }^{103}$ Witness the introduction of mandatory intermediate bank holding companies for the domestic banking operations of foreign-owned financial institutions in the United States, see Federal Reserve System, Enhanced Prudential Standards for Bank Holding Companies and Foreign Banking Organizations (amending 12 CFR 252) ("Regulation YY”) 79 F.R. 17240 (27 March 2014).

${ }^{104}$ See, for further discussion, Binder, ibid.; and see, discussing the implications for the resolvability of the group as a whole, FSB, supra n. 17, pp. 13-14.

${ }^{105}$ For further discussion, see Binder, ibid.

${ }^{106}$ Binder, ibid.; FSB, supra n. 17, pp. 14-15.

${ }^{107}$ FSB, supra n. 17, p. 15.

${ }^{108}$ See Adam J. Levitin, 'The Politics of Financial Regulation and the Regulation of Financial Politics: A Review Essay’, 127 Harv. L. Rev. (2014) 1991, p. 2033-2034.
} 
complex task, as the assessment of such benefits, in turn, needs to consider possible social gains (in terms of greater growth potential) that may be realised only at the expense of greater market volatility. ${ }^{109}$ Given the lack of reliable empirical evidence on the trade-offs between business models, financial, organisational and legal infrastructures, bank profitability and systemic resilience, it is certainly advisable for the relevant authorities to proceed with care, and to improve the empirical basis before engaging into comprehensive structural measures that will substantially change the way banks and banking groups are organised today. If one accepts the residual differences between existing market structures, however, a gradual convergence of regulatory policies in this respect - and, as a result, of the relevant market structures as a whole - may be simply unavoidable over time. This holds true particularly in the Banking Union, where the centralisation of responsibilities and powers comes with both a greater need for consistency and improved ways to accomplish it.

\section{How COUld IT LOOK LiKe? FOUR SCENARIOS AND SOME SPECULATION}

As mentioned before, the future practice with regard to resolution plans will involve a number of yet undecided policy choices, including both the fundamental choice between "single point of entry" and "multiple point of entry" scenarios and the structure of minimum requirements for bail-inable debt. ${ }^{110}$ Whatever solution is ultimately agreed upon, the feasibility will ultimately also depend on how the relevant authorities will use their powers in order to force institutions and groups to reorganise themselves in a way that removes potential impediments to the preferred approach. Some preliminary observations can be made even pending future agreement in this respect. In order to explore how such efforts could evolve in future practice and to illustrate the scope and limitations for relevant policies, it is appropriate to differentiate between a number of - highly stylised - group scenarios which will occur in various different combinations in future practice, but nonetheless highlight some important aspects: (a) a "pure" Banking Union scenario, where all individual group companies and the group as a whole are supervised by the ECB, (b) a "mixed” European scenario, where the ECB acts as consolidating supervisor for a group with branches and/or subsidiaries located within both participating and non-participating Member States, (c) a "mixed” European scenario, with the ECB as competent authority for a subsidiary of a group or a branch of an institution that is under (consolidated) supervision by home authorities in another EU Member State, and (d) a Third Country scenario, where the ECB is the supervisor for a subsidiary of a foreign group.

\footnotetext{
${ }^{109}$ Ibid., p. 2034 (critiquing Anad Admati and Martin Hellwig, The Bankers' New Clothes. What's Wrong with Banking and What to Do about It' (2013), pp. 145-147, 161-166).

${ }^{110}$ See supra, text and nn. 20 and 22.
} 
Consider, first, a group of credit institutions located in different Member States participating in the Banking Union, with both the parent located within the Banking Union and the ECB in charge as consolidating supervisor for the group and competent supervisor for the individual credit institutions and branches. In this scenario, the Single Resolution Board would also be fully responsible for all tasks related to resolution planning at both the individual firm and group levels. ${ }^{111}$ Consequently, both the ECB, in its capacity as competent authority for the assessment for individual and group recovery plans, ${ }^{112}$ and the Single Resolution Board ${ }^{113}$ would be in a position to determine and enforce policies in a rather autonomous way, with only limited influence of national authorities in the respective national markets. In this scenario, the highest possible degree of consistency for the entire group can be expected. ${ }^{114}$

Assuming that the group is organised in a highly integrated way, with a wide range of business functions carried out across the different legal entities, and with capital allocated on a consolidated basis, potential impediments to swift and effective group-wide resolution could result from a variety of sources in such a setting. These could include, inter alia, a high regional concentration of risky business and exposure to specific market risks, ${ }^{115}$ complicated intra-group funding arrangements, ${ }^{116}$ a mismatch between the allocation of capital and liquidity within the group on the one hand and the sources of risks on the other hand, ${ }^{117}$ and/or interdependencies between group companies in terms of the provision of essential operating services (e.g. IT services) across the group.

Taking these features as examples of a wider range of potential problems, it becomes clear, first of all, that not all potential impediments to resolution that emanate from business models, funding, organisational and legal structures can be appropriately addressed by way of the different forms of structural changes discussed above: While a lack of risk diversification certainly is detrimental not just in terms of long-term sustainability, but also in terms of resolva-

\footnotetext{
${ }^{111}$ SRM Regulation, articles 8(1) and 7(2)(a); see supra, section III.

${ }^{112}$ Under articles 6 and 8 of the BRRD and article 4(1)(i) of the SSM Regulation. See, again, supra, section III.

${ }^{113}$ Under articles 8 and 10 of the SRM Regulation.

${ }^{114}$ Cf., again, Babis, [2014] EBLR 459, 477.

${ }^{115}$ Which could, if the relevant regional market enters into significant problems, stand in the way of a swift recovery or resolution, for example, because it may be difficult to restructure or indeed sell off the group's operations under such circumstances.

${ }^{116}$ Which may be difficult to disentangle, where necessary in order to accomplish effective group-wide resolution.

${ }^{117}$ For example, a legal entity operating in a particularly risky type of business may be insufficiently capitalised on a solo basis, which would be problematic upon resolution even if the total assets available in the group are appropriate.
} 
bility, ${ }^{118}$ this and similar deficiencies in existing business models can hardly be corrected merely by top-down administrative intervention in the organisation of the relevant firms and groups; it would be for management and bank owners, not for the ECB or the SRB to define possible remedies and change the business model in this respect. Intra-group funding arrangements, by contrast, will be much easier to deal with, as the legal framework for such arrangements have been harmonised by the BRRD, ${ }^{119}$ and a common approach is likely to emerge within the EU generally in the context of the forthcoming regime on minimum requirements on bail-inable liabilities under article 45 of the BRRD: ${ }^{120}$ In effect, these problems will be, to some extent, addressed through general prudential requirements, not in the context of individual or group recovery and resolution plans. ${ }^{121}$

In the context of recovery and resolution planning, the relevant authorities could, however, try to address issues such as the remaining two problems mentioned above, e.g., by forcing groups to reallocate or consolidate their business and service functions within the existing group landscape. Alternatively, they could force the group to restructure and simplify itself, e.g., by reducing the number of group companies and realign business functions with the legal structure. ${ }^{122}$ A fundamental policy choice to be made in this respect is whether firms and groups should also be required to increase the functional and/or geographical segregation of business activities within the group, e.g., by separating traditional commercial from investment banking services or by reallocating local business to locally incorporated subsidiaries. Both strategies could yield benefits in terms of improved resolvability. However, the case for either would have to be carefully explored within a pure Banking Union scenario, where the centralised responsibility for resolution would mitigate some of the complexities in normal cross-border cases anyhow. Instead, the relevant authorities could opt for a reverse option, by concentrating all business into one legal entity, effectively consolidating existing subsidiaries into the parent. Under the former option, the execution of resolution action would be "regionalised”, under the latter, “centralised”.

Neither the BRRD nor the SSM and SRM Regulations offer clear guidance in this respect. Essentially, the relevant provisions merely require that the implications for systemic stability

\footnotetext{
${ }^{118}$ See again supra, n. 115.

119 BRRD, articles 19-26. EBA is presently engaged in a number of consultations over additional standards and guidelines in this respect: see www.eba.europa.eu/regulation-and-policy/recovery-and-resolution.

${ }^{120}$ See supra, n. 22 and accompanying text.

${ }^{121}$ But note, again, the power for the Board to require institutions and groups to make substantial changes to financial arrangements pursuant to article 10(11) of the SRM Regulation.

${ }^{122}$ Which is presently anticipated by regulators as a potential trend for future structural reforms, see supra, text accompanying n. 95.
} 
in all Member States be duly considered, ${ }^{123}$ be proportionate ${ }^{124}$ and must not discriminate on the grounds of nationality ${ }^{125}$ or prevent the exercise of the Treaty Freedoms of movement. ${ }^{126}$ None of these safeguards would appear to preclude functional separation as a guiding principle for regulatory interference with the organizational choice of institutions and groups within the resolution planning framework. Much the same applies with regard to the choice between regionalisation and decentralisation of resolution by way of structural changes in the form discussed above. As long as the proposed changes can be justified against the benchmark of 'resolvability' on the one hand and the legal safeguards set out above on the other hand, they are permissible under both the BRRD and the SSM and SRM Regulations, and the responsible authorities will enjoy a high degree of discretion in this regard.

This said, even if 'regionalised' groups may be easier to resolve even within the institutional framework of the Banking Union, the likelihood that the ECB or the SRB would actually opt for a strategy aiming at the regionalisation of banking operations within the Eurozone is probably low. Notwithstanding centralised supervisory powers, restructuring existing groups in a way that reallocates regional business to regional subsidiaries will probably be difficult to accomplish without increasing the fragmentation of banking markets within the Banking Union, which would be incompatible with the very rationale of the Banking Union. ${ }^{127}$ It is highly likely, therefore, that the ECB will treat the entire Eurozone as a truly integrated market, which would, for example, rule out the ring-fencing of assets within branches in order to protect the relevant "host" jurisdictions against the risk of insolvency of a bank that is licensed in another Member State, ${ }^{128}$ even if a reliable agreement between host and home countries on ring-fencing could possibly be mutually advantageous in theory. ${ }^{129}$ In this respect, not just the banks, but also the relevant authorities within the Banking Union are confronted with a di-

\footnotetext{
${ }^{123}$ BRRD, Preamble, recitals 14, 23, 34 and articles 12(3) and 16(1); SRM Regulation, Preamble, recital 46, articles 10(3), (5), (10) and 11(11).

${ }^{124}$ BRRD, Preamble, recital 29 and articles 6(6), (7), 10(5), 17(4) and 18(2); SRM Regulation, Preamble, recital 46 and articles 8(6) and 10(7).

${ }^{125}$ BRRD, Preamble, recital 29; SRM Regulation, Preamble, recital 46.

${ }^{126}$ BRRD, Preamble, recital 30.

${ }^{127}$ Cf., e.g., SSM Regulation, Preamble, recital 2: 'The present financial and economic crisis has shown that the integrity of the single currency and the internal market may be threatened by the fragmentation of the financial sector. It is therefore essential to intensify the integration of banking supervision in order to bolster the Union, restore financial stability and lay the basis for economic recovery.'

${ }^{128}$ E.g., speech by Mario Draghi, President of the European Central Bank, at the conference for the 20th anniversary of the establishment of the European Monetary Institute, Brussels, 12 February 2014, available at http://www.bis.org/review/r140213a.htm.

${ }^{129}$ This is at least debatable, but far from settled: see, for further discussion, Binder, supra n. 13; FSB, supra n. 17, pp. 13-14.
} 
lemma between enhanced resolvability and systemic stability, which could be facilitated by regionalisation, and the need to strive for market integration, which would not.

\section{b) “Mixed” European scenario with ECB as consolidating supervisor}

Turning to the second scenario, where the ECB acts as consolidating supervisor for groups with subsidiaries and branches both within the Banking Union and the rest of the EU, the situation prima facie looks less different from 'pure' Banking Union scenarios that could be expected. In this scenario, the ECB, qua consolidating supervisor, and the SRB would retain considerable power to influence the structure of individual firms within their supervision, and of the group as a whole, even though one or more subsidiaries would be supervised by home country authorities in a non-participating Member State. Moreover, the key governing principles for 'pure' Banking Union scenarios, i.e. the need to maintain financial stability across the entire EU, proportionality, non-discrimination, respect for the Treaty freedoms of movement, ${ }^{130}$ equally apply to the relationship between the Banking Union authorities and subsidiaries located in other EU Member States.

Both the ECB, when assessing group recovery plans under the national laws transposing article 7 of the BRRD, and the SRB, as the authority responsible for drawing up group resolution plans and for the assessment of resolvability under articles 8 and 10 of the SRM Regulation, will nonetheless be in a position quite different from a 'pure' Banking Union environment. Arguably, the potential for conflicts with the home supervisors of group companies licensed in non-participating EU Member States, i.e. foreign authorities that are not part of the institutional hierarchy established within the Banking Union, will be higher than vis-à-vis national supervisory and resolution authorities in participating Member States, which occupy a lower rank than the ECB and the SRB, respectively. The same applies with regard to nonparticipating Member States with significant branches of institutions licensed within the Banking Union. Although bound to the principle of non-discrimination and the Treaty freedoms of movement, the ECB and the SRB could find themselves in considerable tensions with the corresponding authorities in non-participating Member States, especially with respect to the allocation of risks (and, correspondingly, the division of powers and responsibilities for resolution action) between jurisdictions within 'mixed' cross-border groups. Conflicting interests to support specific market places (e.g., Frankfurt versus London) could add to that.

While starting from the same set of substantive principles, namely those laid down in the BRRD for the treatment of banks across the entire EU, it is therefore conceivable that the

\footnotetext{
${ }^{130}$ Supra, nn. 123-126.
} 
ECB and the SRB, in their capacity as authorities responsible for consolidated supervision and resolution, might follow a different approach in dealing with subsidiaries or branches that are located in non-participating Member States. In order to enhance the supervisability and resolvability of such groups from the perspective of the Banking Union authorities, they could, for example, use their powers under the recovery and resolution planning framework with a view to concentrating all group business conducted within the Eurozone into legal entities directly under their control. Although in conflict with the Treaty freedoms of movement, ${ }^{131}$ in that it would lead to enhanced disintegration between markets in participating and non-participating Member States and could benefit financial centres within the Banking Union at the expense of others outside, this could be justified on the public policy grounds of systemic stability gains - and, indeed, would be an almost logical consequence of the institutional division between the Banking Union and the rest of Europe.

With regard to branches of Banking Union-licensed institutions that are located in nonparticipating EU Member States and operate under the European Passport, the relevant strategic choices would be even more complex. Whether or not the Banking Union authorities would prefer to maintain the existing branch structure or force the relevant firms or groups to restructure branches into subsidiaries would probably depend on a case-by-case analysis of the respective costs and benefits. From the Banking Union authorities' (home country) perspective, allowing existing extra-territorial branches to continue trading would secure more effective control over business conducted outside the Eurozone both on a going concern and gone concern basis, which could be attractive in cases where the ECB or the SRB are uncomfortable with the strategies employed by the relevant host countries. ${ }^{132}$ On the other hand, this would mean full responsibility for the coordination of resolution action beyond the Eurozone, which could be risky for operational and logistic reasons as well as because of potential turf wars with the relevant home authorities. ${ }^{133}$ Moreover, the full cost of resolution, in this scenario, would be ultimately borne by the Single Resolution Fund, with no direct access to funding mechanisms in the relevant non-participating Member States. Forcing the relevant institu-

\footnotetext{
${ }^{131}$ The forced "subsidiarisation" in this form would essentially cut back on the relevant institutions' right to conduct banking business across the EU under their home country license as a "European Passport", as set out by the CRD IV.

${ }^{132}$ Cf., analysing home and host authorities' incentives with regard to the organisational choice between branches and subsidiaries, Jonathan Fiechter et al., 'Subsidiaries or Branches: Does One Size Fit All?', IM Staff Discussion Note (7 March 2011), available at https://www.imf.org/external/pubs/ft/sdn/2011/sdn1104.pdf, pp. 1618; see also Tobias H. Tröger, 'Organizational Choices of Banks and the Effective Supervision of Transnational Financial Institutions', 48 Tex. Int’l L.J. 177, 194-195 and 197-199 (2013). For an in-depth discussion of potential sources of conflict, cf. Richard J. Herring, 'Conflicts Between Home and Host Country Prudential Supervisors, in: Douglas D. Evanoff, George G. Kaufman and John R. LaBrosse (eds.), International Financial Instability: Global Banking and National Regulation (2007), pp. 201-219; Dirk Schoenmaker, Governance of International Banking - The Financial Trilemma (2013), pp. 69-71.
}

${ }^{133}$ See, again, Babis, [2014] EBLR 459, 474-477. 
tions to restructure their business outside the Eurozone into subsidiaries would avoid these problems, albeit at the price of a reduced control over resolution proceedings on the part of the Banking Union authorities and, correspondingly, an increased dependence on cooperation with the relevant host authorities. ${ }^{134}$

It is not difficult to see that in any of these different scenarios, the result could be enhanced 'regionalisation' along the jurisdictional border between the Banking Union and the rest of the EU in terms of supervisory and resolution powers, but also in the way groups have been organised to date. Although expressly required to adopt a truly European perspective - and respect the interests of non-participating Member States ${ }^{135}$ - under the relevant legal frameworks, both the ECB and SRB may have to be expected to demonstrate an almost natural, and justifiable, bias towards restructuring existing cross-border groups to the disadvantage of markets outside the Banking Union. This could give market centres within the Banking Union (not least, Frankfurt) a competitive edge over their competitors outside their jurisdiction (in particular, London). In sum, the recovery and resolution planning regime could thus prove to be a powerful driver of an increasing division between the two realms, although much will depend on how specifically the Banking Union authorities will use their powers in future practice. In fact, despite the need to comply with the Treaty framework for a level playing field across the entire internal market, firms outside the direct control of the Banking Union authorities could find themselves in a position that is closer to that of Third Country institutions than it is to the position of institutions located within the Banking Union.

\section{“Mixed” European scenario with ECB as host country supervisor over subsidiaries}

licensed within the Banking Union or branches of institutions in non-participating EU Member States

For obvious reasons, the picture would look entirely different in a setting where the ECB, not being the consolidating supervisor, merely assumes the role of the home supervisor for a subsidiary of a firm that is supervised, on a consolidated basis, by the authorities of a nonparticipating Member State, or indeed a (significant) branch of such a firm. In the case of a subsidiary, although the Banking Union authorities would retain the responsibility for recovery and resolution planning for the individual firm, they would not have control over the structure of the entire group. They could be drawn, therefore, into a conflict with their coun-

\footnotetext{
${ }^{134}$ See, again, Fiechter et al., supra n. 132

135 This is most clearly captured by article 17(3) of the SSM Regulation, which requires the ECB, in fulfilling its tasks under the Regulation, to 'respect a fair balance between all participating Member States (...) and (...), in its relationship with non-participating Member States, [to] respect the balance between home and host Member States established in relevant Union Law.'
} 
terparts in non-participating Member States that would amount to a reversed image to the one just described for a scenario for groups under the consolidated supervision by the Banking Union authorities. However, given the relevance of the Eurozone as a market even to institutions licensed in non-participating Member States, chances are that the relative influence of Banking Union authorities on the development of group resolution strategies could well be higher than in the reverse scenario. Even without the powers available to the consolidating supervisor, the ECB and SRB could thus effectively use their powers under the recovery and resolution planning regime in a way that ultimately forces the relevant groups to concentrate all business conducted within the Eurozone in a subsidiary under direct ECB supervision, which could, in the event of an insolvency, be operated on a stand-alone basis. ${ }^{136}$

With regard to the treatment of Eurozone branches of institutions licensed in a nonparticipating Member State, the situation, once again, would be different. Just as in the opposite case discussed above, the policy choice would probably be made on a case-by-case basis, taking into account the trade-off between the advantages of autonomous control of resolution strategies on the one hand and the potential costs on the other hand. Where the Banking Union authorities feel comfortable with the supervisory and resolution practices adopted by the relevant non-Banking Union home authorities, they will probably leave the existing branch structure untouched, which would relieve them of the burden of pursuing independent resolution action in addition to action taken by the responsible home authorities. In such circumstances, the Banking Union authorities could even try to have existing subsidiaries, which are operating under a Banking Union license, restructured into branches of foreign institutions, thus removing the need to act as host resolution authority should the Eurozone business run into problems. Where these conditions are not satisfied, by contrast, just the opposite could happen, and the Banking Union authorities could use their powers to nudge foreign groups into turning their Eurozone branches into subsidiaries.

In sum, even where the responsibility for consolidated supervision is not within the Banking Union, the recovery and resolution planning regime could turn out to be a source of increased disintegration between markets in participating and those in non-participating Member States - regardless of whether existing cross-border business is pursued by branches or by subsidiaries on foreign, non-Eurozone banks.

\footnotetext{
${ }^{136}$ Alternatively, the Banking Union authorities could make arrangements to ring-fence assets located within branches in the Banking Union.
} 
In scenarios where the ECB is acting as supervisor for a subsidiary whose parent company is located in a Third Country outside the EU, the Banking Union's position will look (perhaps surprisingly) similar to the 'mixed' scenario just described. In this regard, the specific contents of the relevant contingency plans and the underlying strategies will depend, to a large extent, on the degree of trust between the Banking Union authorities and the relevant Third Country authorities, which will operate under the framework for cooperation established by the BRRD and the SSM and SRM Regulations. ${ }^{137}$ As a rule, however, just as in relation to groups supervised on a consolidated basis by authorities in a non-participating Member State, the Banking Union authorities, in a Third Country Scenario, will have both powers and incentives to force the subsidiaries under their supervision to reinforce their legal, financial and operational independence from the remainder of the group, so as to facilitate recovery and, ultimately, resolution with minimum impact on the stability of the financial system within the Eurozone. In this respect, the Banking Union authorities would not be restricted by the Treaty freedoms of movement, which - as discussed above - could play a (limited) role as safeguards for the protection of non-Eurozone banks in "mixed" European settings with the ECB as consolidating supervisor. In cases where the foreign group operates a multitude of subsidiaries or branches within the Eurozone, this could even include a restructuring of all Banking Union, or indeed European, business into a holding structure with a holding in a participating Member State, which is expressly envisaged as a possible course of action in both the BRRD and the SRM Regulation. ${ }^{138}$

\section{Conclusions}

Even with a reformed toolbox of state-of-the-art instruments for the resolution and reorganisation of banks and banking groups, complex and opaque organisational, financial and legal structures within banks and banking groups will continue to stand in the way of effective resolution. In order to remove such impediments, supervisory and resolution authorities in Europe, both within and outside the Banking Union, have been provided with a wide range of powers to force the relevant institutions and groups to make appropriate changes. The present paper has analysed these powers and their background in international standard setting and sought to explore how strategies for the future use of these instruments could evolve within the Banking Union. Specifically where the Banking Union authorities (ECB and SRB) are, qua consolidated supervision, in control over the organisational and legal structure of an entire group, they

\footnotetext{
${ }^{137}$ See, in particular, BRRD, Title V, SSM Regulation, article 8, and SRM Regulation, articles 11(d) and 32.

${ }^{138}$ See BRRD, article 17(5)(h), and the identical provision in SRM Regulation, article 10(11)(h).
} 
could use their powers in a way that could enhance further integration of the banking systems within the Banking Union, while driving disintegration between participating and nonparticipating Member States. This would be different where the consolidated supervision is exercised by authorities in non-participating EU Member States, but even in such scenarios, the Banking Union authorities could seek to protect the interests of participating jurisdictions by measures that would increase disintegration, possibly placing strong market places in nonparticipating Member States into a competitive disadvantage. Judging from a purely technical perspective, such policies could perhaps be justified against the benchmark of resolvability of institutions and groups within the Banking Union, on the grounds of increased systemic resilience. However, for the relevant authorities to be able to make the relevant policy choices which may or may not include the measures discussed above - and to calibrate the relevant instruments in scope and content, further research into the relevant trade-offs between business models, funding arrangements, organisational and legal structures on the one hand and resolvability and systemic stability on the other hand is certainly essential. The available evidence that exists to date is hardly a sufficient basis for a drastic reorganisation of present firm and group structures in this respect. 


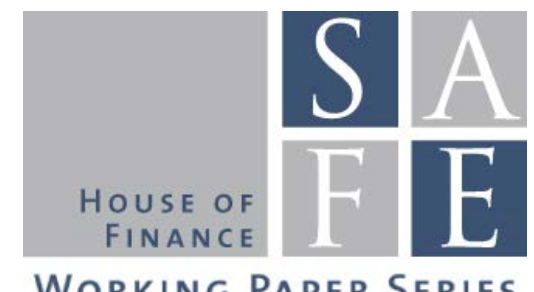

WORKINg PAPER SERIES

\section{Recent Issues}

No. 80 Enrique G. Mendoza, Linda L. Tesar, Jing Zhang

No. 79 Òscar Jordà, Alan M. Taylor

No. 78 Harris Dellas, Dirk Niepelt

No. 77 Benjamin Born, Gernot J. Müller, Johannes Pfeifer

No. 76 Alberto Alesina, Carlo Favero, Francesco Giavazzi

No. 75 Markus Behn, Rainer Haselmann, Vikrant Vig

No. 74 Nicole Branger, Patrick Konermann, Christoph Meinerding, Christian Schlag

No. 73 Max Groneck, Alexander Ludwig, Alexander Zimpel

No. 72 Alexander Ludwig, Matthias Schön

No.71 Daniel Harenberg, Alexander Ludwig

No. 70 Deyan Radev

No. 69 Nina Biljanovska, Spyros Palligkinis

No. 68 Tobias Tröger

No. 67 Sascha Baghestanian, Paul J. Gortner, Joel van der Weele

No. 66 Tobias Tröger
Saving Europe?: The Unpleasant Arithmetic of Fiscal Austerity in Integrated Economies

The Time for Austerity: Estimating the Average Treatment Effect of Fiscal Policy

Austerity

Does Austerity Pay Off?

The Output Effect of Fiscal Consolidation Plans

The Limits of Model-Based Regulation

Equilibrium Asset Pricing in Networks with Mutually Exciting Jumps

A Life-Cycle Model with Ambiguous Survival Beliefs

Endogenous Grids in Higher Dimensions: Delaunay Interpolation and Hybrid Methods

Social Security in an Analytically Tractable Overlapping Generations Model with Aggregate and Idiosyncratic Risk

Assessing Systemic Fragility - a Probabilistic Perspective

Control Thyself: Self-Control Failure and Household Wealth

How Special Are They? - Targeting Systemic Risk by Regulating Shadow Banking

Peer Effects and Risk Sharing in Experimental Asset Markets

Corporate Groups 